\title{
Influência de diferentes tipos de micro-organismos na contagem bacteriana total por citometria de fluxo do leite cru refrigerado
}

\author{
[Influence of different types of microorganisms in total bacterial count by flow \\ cytometry of refrigerated raw milk] \\ V.S.C. Sampaio, F.N. Souza, C.J.C. Saraiva, R.P. Santos, M.O. Leite, G.M. Resende, \\ N.C. Gonçalves, F.L. Dionizio, M.M.O.P. Cerqueira* \\ Escola de Veterinária - Universidade Federal de Minas Gerais - UFMG - Belo Horizonte, MG

\section{RESUMO}

Contagens bacterianas de 179 amostras de leite cru refrigerado, provenientes de diferentes bacias leiteiras de Minas Gerais, foram realizadas pelos métodos de citometria de fluxo e contagem padrão em placas. $\mathrm{O}$ estudo das associações entre a contagem bacteriana total e as contagens bacterianas dos diferentes grupos de micro-organismos foi realizado pela correlação de Pearson. Houve uma forte correlação positiva e significativa entre os valores de contagem de psicrotróficos $(r=0,67)$ e mesófilos $(r=0,70)$, determinados pelo método de referência, e os valores da contagem bacteriana total, determinados pela citometria de fluxo. Foi possível estabelecer uma curva de calibração para o citômetro de fluxo utilizando equações de regressão linear. As equações para a contagem bacteriana obtida por citometria de fluxo em função da contagem de mesófilos e psicrotróficos foram: $\log (\mathrm{CBI})=0,701 \log$ mesófilos $+1,9091 \mathrm{e} \log$ $(\mathrm{CBI})=0,4703 \log$ psicrotróficos $+3,2784$, respectivamente. Não foi possível estabelecer curvas de calibrações para termófilos e termodúricos, pois as correlações obtidas entre as contagens desses microorganismos e a contagem bacteriana total, determinada por citometria de fluxo, foram fracas $(\mathrm{r}=0,30 \mathrm{e}$ 0,27 , respectivamente).

Palavras-chave: leite de tanque, qualidade de leite, leite

\begin{abstract}
Total Bacterial count was performed in 179 raw milk samples from different dairy farms in Minas Gerais State, Brazil, through flow cytometry and standard plate count, that was regarded as the reference method. There was significant strong correlation between the values of psychrotrophic and mesophilic counts determined by the reference method with the values of bacterial count determined by flow cytometry ( $r=0.67$ and 0.70, respectively), which allowed to establish linear regression equations for bacterial count to calibrate the flow cytometry and estimate the count of mesophilic (log bacterial individual count $($ BIC) by flow cytometry $=0.701 \log$ mesophilic +1.9091$)$ and psychrotrophic (log BIC by flow cytometry $=0.4703$ log psychrotrophic +3.2784 ) bacteria. It was not possible to establish calibration curves for thermophiles and thermodurics due to the weak to moderate correlation coefficients found among these microorganism counts and total bacterial count determined by flow cytometry $(r=0.30$ and 0.27 , respectively).
\end{abstract}

Keywords: bulk tank milk, milk quality, milk

\section{INTRODUÇÃO}

A qualidade do leite de tanque pode ser avaliada por inúmeros parâmetros, e dentre esses

Recebido em 24 setembro de 2013

Aceito em 10 de junho de 2014

*Autor para correspondência (corresponding author)

E-mail: monicamopc@ufmg.br parâmetros destaca-se a contagem bacteriana total, que reflete, a priori, a condição higiênica da obtenção do leite na fazenda. Assim, o leite pode ser contaminado por micro-organismos provenientes da microbiota presente no ambiente, de falhas no manejo de ordenha, da 
água e do úbere. No entanto, apenas as bactérias mesofílicas (contagem bacteriana total do leite de tanque) têm sido "alvo" dos vários limites estabelecidos por diferentes países (Pantoja et al., 2009; De Garnica et al., 2013), entre eles o Brasil (Brasil, 2002; Brasil, 2011). Nesse ínterim, outros grupos de bactérias, como as bactérias termodúricas - que são resistentes à pasteurização, geralmente relacionadas à sanitização imprópria dos equipamentos e relacionadas à deterioração do leite pasteurizado -, as bactérias termófilas - que podem ser responsáveis pela degradação proteolítica do leite -, e as bactérias psicotróficas - que podem crescer em baixas temperaturas, geralmente provenientes da sujidade presente nos animais e equipamentos -, são importantes grupos bacterianos que podem influenciar também a qualidade do leite (Jayarao et al., 2004).

A contagem padrão em placas é a técnica de referência para a contagem bacteriana total. Baseia-se na viabilidade bacteriana, ou seja, na capacidade de as bactérias formarem colônias em meio de cultura sólido ou de se proliferarem em meio líquido. Em virtude do tempo gasto para a execução dos métodos de referência, métodos rápidos, baseados na citometria de fluxo, têm sido usados para contagem bacteriana total (CBT) e também para a contagem de células somáticas (CCS) (Holm et al., 2004; Jarayao et al., 2004; Pantoja et al., 2009; Cassoli et al., 2010; De Garnica et al., 2013).

Considerando a escassez de informações na literatura, este trabalho se propôs a avaliar a influência de diferentes grupos de microorganismos, entre eles os micro-organismos mesófilos, psicotróficos, termófilos e termodúricos, presentes no leite de tanque, sobre a contagem bacteriana total por citometria de fluxo.

\section{MATERIAL E MÉTODOS}

Foram coletadas 179 amostras de leite in natura, provenientes de amostras de tanque de expansão de propriedades leiteiras localizadas no Estado de Minas Gerais. As amostras foram acondicionadas, no momento da coleta, em frascos estéreis, contendo azidiol, e foram transportadas até o laboratório em caixas térmicas com gelo reciclável, permanecendo sob refrigeração $\left(4^{\circ} \mathrm{C}\right)$ durante esse período.
As contagens padrão em placas de mesófilos, psicrotróficos e termodúricos foram realizadas segundo IDF (1991). Já a contagem de termófilos foi executada segundo APHA (1992). A contagem bacteriana por citometria de fluxo foi realizada no equipamento BactoCount IBC (Bentley Instruments Incorporated ${ }^{\circledR}$, Chaska, EUA).

Os valores de contagens bacterianas foram convertidos para logaritmo de base dez, já que esses dados não apresentaram distribuição normal. O teste $\mathrm{T}$ de Student para amostras pareadas foi utilizado para confrontar a contagem bacteriana padrão em placas de mesófilos com a contagem bacterina por citometria de fluxo. A correlação de Pearson foi utilizada para avaliar a associação entre a contagem bacteriana total por citometria de fluxo e a contagem padrão em placas dos diferentes tipos de micro-organismos. Para determinar a curva de calibração da contagem bacteriana total pela citometria de fluxo, considerando a contagem bacteriana padrão em placa para cada tipo de microorganismo, a regressão linear foi utilizada para determinar a equação da reta. A correlação foi considerada como baixa $(\mathrm{r}<0,30)$, moderada $(\mathrm{r}$ entre 0,3 e 0,6$)$ ou elevada $(r>0,60)$ (Sampaio, 2010).

\section{RESULTADOS E DISCUSSÃO}

Verificou-se que não houve concentração de amostras nas classes de baixa ou alta contagem bacteriana total. Se tal fato ocorresse, poderia influenciar a curva de calibração do equipamento Bactocount IBC ${ }^{\circledR}$ (Tab. 1).

Os resultados para a CBT por citometria de fluxo $(5,59+0,94)$ foram maiores que a contagem padrão em placas $(5,28+0,93 ; \mathrm{P}<0,05)$, como relatado por Holm et al. (2004). O principal motivo dessa discrepância deve-se ao fato de que a contagem padrão em placas pode subestimar a quantidade total de bactérias, uma vez que apenas as bactérias viáveis crescem no meio de cultura, sendo então expresso em UFC. Deve-se ressaltar ainda que uma colônia nem sempre se constitui de uma única célula bacteriana, e apenas os micro-organismos cultiváveis, ou seja, aqueles que se desenvolvem nas condições de plaqueamento das amostras, são enumerados. Outras desvantagens da contagem bacteriana em 
placa são seu alto custo e baixo desempenho analítico (Cassoli et al., 2010). Já a citometria de fluxo é considerada um método de rotina automatizado, de alto desempenho e baixo custo (Suhren e Walte, 1998; Gunasekera et al., 2000).

Tabela 1. Distribuição das amostras de leite cru refrigerado em classes de acordo com a contagem bacteriana total

\begin{tabular}{cccc} 
Classificação & $\begin{array}{c}\text { Contagem bacteriana } \\
(\text { UFC/mL) }\end{array}$ & Número de amostras & Porcentagem \\
\hline Muito Baixa & $0-50.000$ & 53 & 29,61 \\
\hline Baixa & $50.001-100.000$ & 27 & 15,08 \\
\hline Média & $100.001-750.000$ & 69 & 38,55 \\
\hline Alta & $750.001-1.000 .000$ & 9 & 11,73 \\
\hline Muito Alta & $>1.000 .000$ & 21 & \\
\hline
\end{tabular}

UFC: unidade formadora de colônia.

Para a conversão da contagem bacteriana individual $(\mathrm{CBI} / \mathrm{mL})$ obtida pela citometria de fluxo para $\mathrm{UFC} / \mathrm{mL}$, unidade em que os resultados obtidos pela técnica de referência são expressos, é necessária a utilização de uma equação de conversão. Em países onde existem vários laboratórios de controle de qualidade do leite (conhecidos internacionalmente como Central Milk Testing) é essencial que os diferentes equipamentos utilizados em cada um dos laboratórios gerem resultados similares, tanto para contagem bacteriana individual quanto para unidades formadoras de colônia. Onze países da Europa definiram uma equação de conversão nacional. Alguns deles adotaram também equações de conversão entre países vizinhos (Suhren e Lombardi, 2006). No entanto, no Brasil, cada laboratório desenvolveu sua equação de conversão.
A International Dairy Federation (IDF) afirma que fatores como o tipo de bactéria, o seu estado fisiológico, características de agregação, entre outros, podem influenciar a conversão dos resultados de $\mathrm{CBI} / \mathrm{mL}$ para $\mathrm{UFC} / \mathrm{mL}$. Considerando-se as diferenças existentes entre as propriedades leiteiras brasileiras, tais como clima, rebanho e manejo, é de se esperar que o leite contenha uma população bacteriana diversificada em função de sua origem (Cempírková, 2002; De Garnica et al., 2013). Isso pode levar à obtenção de resultados pouco precisos quando o leite for analisado fora de sua região de origem, em equipamento calibrado com amostras contendo uma microbiota diferente.

A associação entre cada grupo de microorganismos do leite e a contagem bacteriana obtida por citometria de fluxo foi avaliada pela correlação de Pearson (Tab. 2).

Tabela 2. Coeficientes de correlação entre a contagem bacteriana total obtida pela citometria de fluxo e as CPP de micro-organismos psicrotróficos, mesófilos, termófilos e termodúricos

\begin{tabular}{cccccc}
$\begin{array}{c}\text { Contagem } \\
\text { Bacteriana }\end{array}$ & $\begin{array}{c}\text { Citometria de } \\
\text { fluxo }\end{array}$ & $\begin{array}{c}\text { CPP de } \\
\text { psicotróficos }\end{array}$ & $\begin{array}{c}\text { CPP de } \\
\text { mesófilos }\end{array}$ & $\begin{array}{c}\text { CPP de } \\
\text { termófilos }\end{array}$ & $\begin{array}{c}\text { CPP de } \\
\text { termodúricos }\end{array}$ \\
\hline $\begin{array}{c}\text { Citometria de } \\
\text { fluxo }\end{array}$ & - & $0,67^{*}$ & $0,70^{*}$ & $0,30^{*}$ & $0,27^{*}$ \\
\hline $\begin{array}{c}\text { CPP de } \\
\text { psicotróficos }\end{array}$ & - & - & $0,79^{*}$ & $0,34^{*}$ & $0,32^{*}$ \\
\hline $\begin{array}{c}\text { CPP de } \\
\text { mesófilos }\end{array}$ & - & - & - & $0,25^{*}$ & $0,32^{*}$ \\
\hline $\begin{array}{c}\text { CPP de } \\
\text { termófilos }\end{array}$ & - & - & - & - & $0,18^{*}$ \\
\hline $\begin{array}{l}\text { CPP de } \\
\text { termodúricos }\end{array}$ & - & - & - & - \\
\hline CPP: contagem padrão em placa. ${ }^{*} P \leq 0,01$. & & &
\end{tabular}


Foram observadas correlações positivas muito altas entre a CBT por citometria de fluxo e a contagem bacteriana dos micro-organismos mesófilos $(r=0,70)$ e psicrotróficos $(r=0,67)$, respectivamente. Semelhante ao presente estudo, Cempírková (2002) também encontrou uma alta correlação positiva entre a contagem de microorganismos psicrotróficos e a CBT por citometria de fluxo $(r=0,69)$. A população bacteriana predominante no leite é representada por bactérias Gram-negativas (80\%), sendo que o genêro Pseudomonas spp. representa 50 a $70 \%$ desse grupo. Bactérias do gênero Pseudomonas spp. multiplicam-se em uma ampla faixa de temperatura, de 4 a $30^{\circ} \mathrm{C}$, sendo $25^{\circ} \mathrm{C}$ sua temperatura ótima de crescimento (Martins et al., 2006; Arcuri et al., 2008; Cassoli et al., 2010), fato que pode explicar os resultados encontrados no presente estudo.

As bactérias psicrotróficas têm recebido grande atenção, devido, em parte, à capacidade de produção de proteases, lipases, e fosfolipases, que são resistentes ao calor, e consequentemente ao processo de pasteurização do leite. Dessa forma, alguns países europeus, diferentemente do Brasil, estabeleceram limite para esse grupo de bactérias (até $50.000 \mathrm{UFC} / \mathrm{mL}$ ), sendo proposto ainda que a contagem desse grupo bacteriano não deve exceder a 1/6 da CBT. Dessa forma, o aumento da contagem desse grupo de microorganismos pode aumentar a proporção de bactérias proteolíticas e lipolíticas, e levar a problemas no processamento do leite (Cempírková, 2002).

A contagem bacteriana de micro-organismos termófilos $(\log 2,79 \pm 0,60 \mathrm{UFC} / \mathrm{mL})$ e termodúricos $(\log 3,09 \pm 0,85 \mathrm{UFC} / \mathrm{mL})$ apresentaram baixas correlações positivas com $\mathrm{o}$ resultado de contagem bacteriana total obtido por citometria de fluxo (Tab. 2). Os baixos coeficientes encontrados se devem às baixas contagens de termófilos e termodúricos nas amostras de leite cru refrigerado analisadas. Entretanto, salienta-se que, mesmo quando presentes no leite em proporções menores, os micro-organismos termodúricos podem deteriorar o leite e os produtos lácteos, devido ao fato de sobreviverem à pasteurização e se multiplicarem durante a vida de prateleira do leite e dos produtos lácteos.

Em virtude da forte correlação encontrada entre os valores das contagens de mesófilos e psicrotróficos obtidos pela técnica padrão com a CBT determinada pela citometria de fluxo, foi possível estabelecer equações de regressão linear entre essas variáveis. Para os micro-organismos mesófilos, foi estabelecida a seguinte equação: $\log \mathrm{CBI}=0,701 \log$ mesófilos $+1,9091$, em que o logaritmo de base dez do valor da CBI determinada por citometria de fluxo (log CBI) é a variável dependente, e logaritmo da base dez do valor da contagem de mesófilos (log mesófilos), determinado pelo método padrão, é a variável independente. Já para os psicrotróficos, a equação estabelecida foi: $\log \mathrm{CBI}=0,4703 \log$ psicrotróficos $+3,2784$, onde o logaritmo de base dez do valor da contagem bacteriana determinada por citometria de fluxo (log CBI) é a variável dependente, e o logaritmo da base dez do valor da contagem de psicrotróficos (log psicrotróficos), determinado pelo método padrão, é a variável independente. As curvas de regressão para micro-organismos mesófilos e psicotrófilos estão representadas nas Figuras 1 e 2 , respectivamente.

Assim, essas equações poderão ser utilizadas para calibrar o equipamento Bactocount IBC. Nesse contexto, salienta-se que a demanda por análises de psicrotróficos em amostras de leite tem sido frequente. Com a calibração do equipamento especificamente para esse grupo de micro-organismos, será possível estimar a contagem bacteriana desses micro-organismos rapidamente utilizando-se a citometria de fluxo. Não foi possível estabelecer curvas de calibrações para micro-organismos termófilos e termodúricos, pois os coeficientes de correlação obtidos entre a contagem desses microorganismos e a contagem bacteriana total, determinada por citometria de fluxo, foram baixos. 


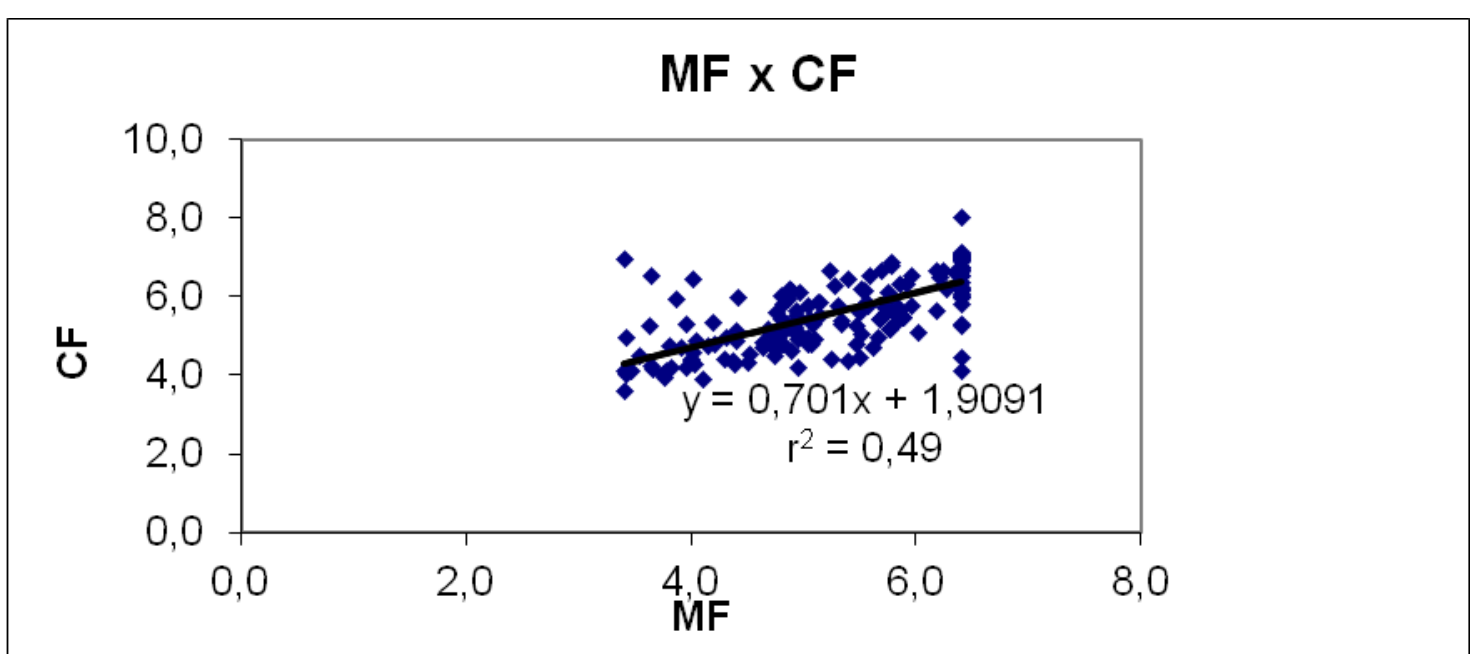

Figura 1. Curva de regressão linear entre a contagem bacteriana determinada por citometria de fluxo (CF) e contagem bacteriana padrão em placas para os micro-organismos mesófilos (MF).

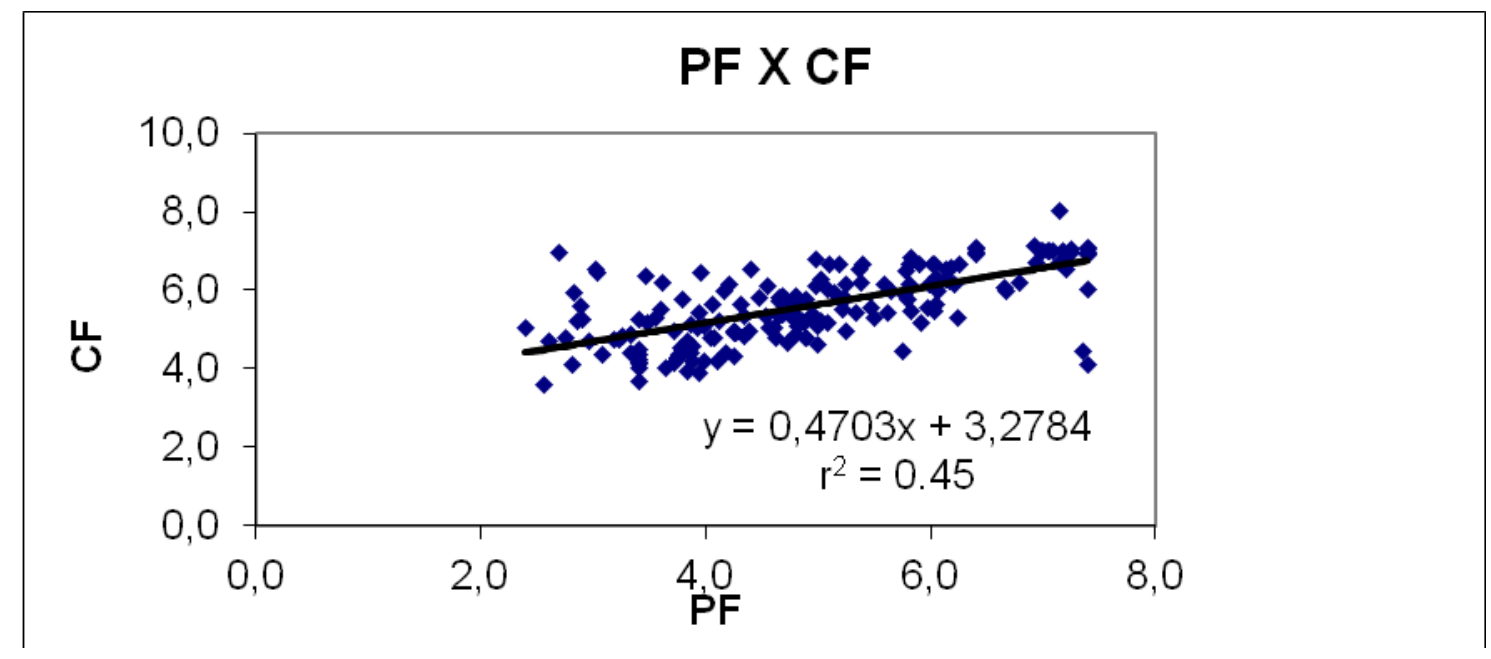

Figura 2. Curva de regressão linear entre a contagem bacteriana determinada por citometria de fluxo (CF) e contagem bacteriana padrão em placas para os micro-organismos psicrotróficos (PF).

\section{CONCLUSÕES}

O presente estudo encontrou uma alta correlação positiva e significativa entre a contagem de micro-organismos psicrotróficos e mesófilos (enumerados através do método de referência) e os valores de contagem bacteriana obtidos por citometria de fluxo, o que permitiu estabelecer curvas de calibração para o equipamento Bactocount IBC $^{\circledR}$ em função desses dois grupos bacterianos. A baixa associação entre os valores obtidos da contagem padrão em placas de micro- organismos termófilos e de termodúricos e os valores de contagem bacteriana determinados pela citometria de fluxo inviabilizou a calibração do equipamento eletrônico para análise desses micro-organismos por citometria de fluxo.

\section{AGRADECIMENTOS}

Os autores agradecem a contribuição e suporte do Laboratório de Qualidade de Leite da Escola de Veterinária da Universidade Federal de Minas Gerais (LabUFMG). 


\section{REFERÊNCIAS}

APHA. American Public Health Association. Standard Methods for the examination of dairy products. 16th ed. Washington: APHA, 1992. $546 \mathrm{p}$.

ARCURI, E.F.; SILVA, P.D.L.; BRITO, M.A.V.P. et al. Contagem, isolamento e caracterização de bactérias psicrotróficas contaminantes de leite cru refrigerado. Cienc. Rural, v.38, p.2250-2255, 2008.

BRASIL. Ministério da Agricultura Pecuária e Abastecimento. Instrução normativa n.51, de 18 de setembro de 2002.Regulamento Técnico de Produção, Identidade e Qualidade do Leite tipo $A$, do leite tipo $B$, do leite tipo $C$, do leite pasteurizado e do leite cru refrigerado e o Regulamento Técnico da coleta de leite cru refrigerado e seu transporte a granel. Diário Oficial da União, Brasília, p. 13, 18 de setembro de 2002. Seção 1 .

BRASIL. Ministério da Agricultura Pecuária e Abastecimento. Instrução normativa n. 62, de 29 de dezembro de 2011. Regulamento Técnico de Produção, Identidade e Qualidade do Leite tipo $A$, do leite tipo $B$, do leite tipo $C$, do leite pasteurizado e do leite cru refrigerado e o Regulamento Técnico da coleta de leite cru refrigerado e seu transporte a granel. Diário Oficial da União, Brasília, p. 6, 29 de dezembro de 2011. Seção 1.

CASSOLI, L.D.; FRANCISCHETTI, G.; MACHADO, P.F. et al. The relationship of flow cytometry results with classical measures of bacterial counts in raw milk refrigerated milk. Int. J. Dairy Technol., v.63, p.297-300, 2010.

CEMPÍRKOVÁ, R. Psychrotrophic vs. Total bacteria counts in bulk milk samples. Vet. Med. Czech, v.47, p.227-233, 2002.
DE GARNICA, M.L.; LINAGE, B.; CARRIEDO, J.A. Relationship among specific bacterial counts and total bactéria and somatic cell counts and factors influencing their variation in ovine bulk tank milk. J. Dairy Sci., v.96, p.1021-1029, 2013.

GUNASEKERA, T.S.; ATTFIELD, P.V.; VEAL, D.A. A flow cytometric method for rapid detection and enumeration of total bacteria in milk. Appl. Environ. Microb., v.66, p.1228-1232, 2000.

HOLM, C.; MATHIASEN, T.; JESPERSEN, L.A. flow cytometric technique for quantification and differentiation of bacteria in bulk tank milk. J. Appl. Microbiol., v.97, p.935-941, 2004.

IDF. International IDF Standard 100B:1991. Milk and milk products - Enumeration of microorganisms - Colony count technique at $30^{\circ} \mathrm{C}$. Brussels, 3f, 1991.

JAYARAO, B.M.; PILLAI, S.R.; SAWANT, A.A. et al. Guidelines for monitoring bulk tank milk somatic cell and bacterial counts. J. Dairy Sci., v.87, p.3561-3573, 2004.

MARTINS, M.L., PINTO, C.L.O., ROCHA, R.B. et al. Genetic diversity of Gram-negative, proteolytic, psychrotrophic bactéria isolated from refrigerated raw milk. Int. J. Food Microbiol., v.111, p.144-148, 2006.

PANTOJA， J.C.M.; REINEMANN， D.J.; RUEGG, P.L. Associations among milk quality indicators in raw bulk milk. J. Dairy Sci., v.92, p.4978-4987, 2009.

SAMPAIO, I.B.M. Estatística aplicada à experimentação animal. Belo Horizonte: Fundação de Ensino e Pesquisa em Medicina Veterinária e Zootecnia, 2010. 264p.

SUHREN, G., LOMBARDI, B. Determination of total bacterial count in raw milk in EU-Members states: outcome of the 2006 questionnaire to the NRL's Milk, 2006. Disponível em: <http://www.rikilt.wur.nl/NL/publicaties/Rappor ten/>. Acessado em: 12 set. 2010. 